\title{
BIOCHEMISTRY
}

\section{Coupling between Pyruvic Acid Dehydrogenation and Adenylic Acid Phosphorylation}

A NEw coupling of oxidoreduction and phosphorylation, with thiamin (vitamin $B_{1}$ ) pyrophosphate as a link of the reaction chain, was found with dry preparations of Bacterium Delbrïckii (Acidificans longissimum). Phosphorylation of added adenylic acid occurs when pyruvic acid is dehydrogenated, and, as reported previously ${ }^{1}$, thiamin pyrophosphate is the prosthetic of the enzyme catalysing the dehydrogenation of pyruvic acid.

When a suspension of certain bacterial preparations, containing very little adenylpyrophosphatase, is shaken with air in the presence of pyruvic and adenylic acid, the oxygen consumption is accompanied by disappearance of inorganic phosphate.

Table 1.

\begin{tabular}{|c|c|c|c|c|}
\hline & $\begin{array}{c}\text { Initial } \\
\text { value }\end{array}$ & $\begin{array}{c}0.125 \mathrm{~mol} \\
\text { pyruvate }\end{array}$ & $\begin{array}{c}0.125 \mathrm{~mol} \\
\text { pyruvate } \\
0.03 \mathrm{~mol} . \\
\text { adenylic acid }\end{array}$ & $\begin{array}{c}- \\
0.03 \mathrm{~mol} . \\
\text { adenylic acid }\end{array}$ \\
\hline $\begin{array}{c}\text { Mgm. inor- } \\
\text { ganic P ('ml') }\end{array}$ & 0.59 & 0.53 & 0.31 & 0.59 \\
$\begin{array}{c}\text { Mgm. } \\
\text { easily hydro- } \\
\text { lysed P }\end{array}$ & 0 & $0.06(42)$ & $0.28(200)$ & 0.01 \\
- ml O2 & - & 490 & 474 & 58 \\
\hline$-\mathrm{P}:-\frac{1}{2} \mathrm{O}_{2}$ & - & 0.04 & 0.21 & - \\
\hline
\end{tabular}

Aerobic experiment: $c a .35 \mathrm{mgm}$. dried bacteria, suspended in 0.05 mol. sodium fluoride-phosphate solution, were shaken with ai at $37.5^{\circ}$ for an hour.

Equation: pyruvate $\left(\mathrm{H}_{2} \mathrm{O}\right)+\frac{1}{2} \mathrm{O}_{3}=$ acetate $+\mathrm{CO}_{2}+\mathrm{H}_{2} \mathrm{O}$.

The organic phosphate compound formed is split by seven minutes hydrolysis with normal hydrochloric acid (see second line of Table 1). Since tests for phosphopyruvic acid were negative, this is taken as evidence for adenosinpolyphosphate synthesis.

As reported elsewhere ${ }^{1}$, dismutation is very poor with the dried bacteria, but can be developed by the addition of riboflavin ${ }^{2}$. The analysis showed dismutation to be a fermentation-like reaction with pyruvic acid-pyruvic dehydrogenase as reductant, pyruvic acid-lactic dehydrogenase as oxidant and flavin acting as hydrogen carrier between the two enzymatic systems. The reductant is the same both in aerobic dehydrogenation and in anaerobic dismutation of pyruvic acid. The oxidants, however, are different, being oxygen in the first case and pyruvic acid-lactic dehydrogenase in the second.

It appears from the anaerobic experiment shown in Table 2 that the dismutative reaction also gives rise to phosphorylation.

Table 2.

\begin{tabular}{|c|c|c|c|}
\hline ; & $\begin{array}{l}\text { Initial } \\
\text { value }\end{array}$ & $\begin{array}{c}0.125 \mathrm{~mol} . \\
\text { pyruvate } \\
0.03 \mathrm{~mol} . \\
\text { adenylic acid } \\
--\end{array}$ & $\begin{array}{c}0.125 \mathrm{~mol} . \\
\text { pyruvate } \\
0.03 \mathrm{~mol} . \\
\text { adenylic acid } \\
0.1 \mathrm{mgm} . \\
\text { riboflavin }\end{array}$ \\
\hline $\begin{array}{l}\text { Mgm. Inorganic P } \\
\text { Mgm. ('ml') easily } \\
\text { hydrolysed } \mathrm{P} \\
\text { Ml. CO, }\end{array}$ & $\begin{array}{l}0.6 \\
0 \\
\end{array}$ & $\begin{array}{c}0.59 \\
0.01 \\
5\end{array}$ & $\begin{array}{c}0.41 \\
0.19(138) \\
172\end{array}$ \\
\hline$-\mathrm{P}: \mathrm{CO}_{3}$ & 一 & 一 & 0.8 \\
\hline
\end{tabular}

Anaerobic experiment: as aerobic experiment, only with nitrogen. Equation: pyruvate $\left(\mathrm{H}_{2} \mathrm{O}\right)+$ pyruvate $=$ acetate $+\mathrm{CO}_{2}+$ lactate
Since the coupling takes place anaerobically as well as aerobically, it should be independent of the hydrogen acceptor but intimately associated with the dehydrogenation process catalysed by the mediation of thiamin pyrophosphate. In this connexion, it must be considered that inorganic phosphate is an indispensable component of the pyruvic acid dehydrogenation system ${ }^{1}$. A very close resemblance might exist between the function of the pyridine nucleotide in the coupling reaction in fermentation, analysed by Meyerhof ${ }^{3}$ and by Needham ${ }^{4}$ in detail, and the function of the thiazole derivative in our reaction ${ }^{5}$.

In my opinion, the linkage between the thiamin and adenylic acid systems will prove to be of great importance for the understanding of the metabolic function of thiamin in the living cell. A new source of phosphorylation energy appears which can be utilized both aerobically and possibly anaerobically. The skeletal muscle and to a still greater extent the heart muscle are probably supplied with energy from this source. It is well known that heart failure is one of the most conspicuous symptoms of $B_{1}$-avitaminosis ${ }^{6}$ and, according to Birch and Mapson ${ }^{7}$, the inability of the heart to dispose of free adenylic acid is the cause of the bradycardia of animals deprived of thiamin. Also, the oxidative phosphorylations in kidney and liver, reported by Kalckar ${ }^{8}$, might be linked in part to the thiamin system.

I wish to express my sincere thanks to the Ella Sachs Plotz Foundation for the aid given to this work. The adenylic acid was very kindly supplied to me by Dr. P. Ostern.

Biological Institute,

Carlsberg Foundation, Copenhagen.

Jan. 7.

${ }^{1}$ Lipmann, Enzymologia, 4, 65 (1937).

${ }^{2}$ Lipmann, Sixteenth Internat. Physiol. Congress, Zurich, 1938, Ber., 2,161 .

${ }^{3}$ Meyerhof, Ohlmeyer and Möhle, Biochem. Z., 297, 90 (1938).

${ }^{4}$ Needham and Lu, Biochem. J., 32, 2040 (1938).

${ }^{5}$ Lipmann and Perlmann, J. Amer. Chem. Soc., 60, 2575 (1938).

"See review by Williams and Spiess, "Vitamin $B_{2}$ ", New York (1938).

'Birch and Mapson, Nature, 138, 27 (1936).

${ }^{8}$ Kalckar, NATURE, 142, 871 (1938).

\section{Effect of Nicotinic Acid Deficiency on the Cozymase Content of Tissues}

IT is now well recognized, largely through the efforts of the Euler and Warburg laboratories, that nicotinic acid amide is a constituent of both coenzyme I and coenzyme II. Since these coenzymes have such an important role in the metabolic processes of the body, it is of decided importance to acquire more information concerning their physiology. A good deal has been learned from studies with synthetic enzyme systems in which these coenzymes are involved. The in vivo approach has been attempted by the Euler group. They have confined themselves to rats as the experimental animals and have encountered many obstacles in their work, since it has been very difficult to demonstrate a clear-cut deficiency in the rat of the coenzymes or of any of their possible precursors. Recently, however, Elvehjem and co-workers ${ }^{1}$ have demonstrated a 